\title{
AT-Rich Interactive Domain-Containing Protein 4B
}

National Cancer Institute

\section{Source}

National Cancer Institute. AT-Rich Interactive Domain-Containing Protein 4B. NCI

Thesaurus. Code C21531.

AT -rich interactive domain-containing protein 4B (1312 aa, $\sim 148 \mathrm{kDa})$ is encoded by the human ARID4B gene. This protein plays a role in transcriptional repression. 